\title{
Distinct Biphasic mRNA Changes in Response to Asian Soybean Rust Infection
}

\author{
Martijn van de Mortel, ${ }^{1}$ Justin C. Recknor, ${ }^{2}$ Michelle A. Graham, ${ }^{3}$ Dan Nettleton, ${ }^{2}$ Jaime D. Dittman, ${ }^{1}$ \\ Rex T. Nelson, ${ }^{3}$ Cláudia V. Godoy, ${ }^{4}$ Ricardo V. Abdelnoor, ${ }^{4}$ Álvaro M. R. Almeida, ${ }^{4}$ Thomas J. Baum, ${ }^{1}$ and \\ Steven A. Whitham ${ }^{1}$
}

${ }^{1}$ Department of Plant Pathology, ${ }^{2}$ Department of Statistics, and ${ }^{3}$ United States Department of Agriculture-Agricultural Research Service CICGR Unit and Department of Agronomy, lowa State University, Ames 50011, U.S.A.; ${ }^{4} \mathrm{Embrapa}$ Soybean Research Center, Cx P 231, Londrina, 86001-970 PR, Brazil

Submitted 30 March 2007. Accepted 30 April 2007.

\begin{abstract}
Asian soybean rust (ASR), caused by Phakopsora pachyrhizi, is now established in all major soybean-producing countries. Currently, there is little information about the molecular basis of ASR-soybean interactions, which will be needed to assist future efforts to develop effective resistance. Toward this end, abundance changes of soybean mRNAs were measured over a 7-day ASR infection time course in mock-inoculated and infected leaves of a soybean accession (PI230970) carrying the $R p p 2$ resistance gene and a susceptible genotype (Embrapa-48). The expression profiles of differentially expressed genes (ASR-infected compared with the mockinoculated control) revealed a biphasic response to ASR in each genotype. Within the first $12 \mathrm{~h}$ after inoculation (hai), which corresponds to fungal germination and penetration of the epidermal cells, differential gene expression changes were evident in both genotypes. mRNA expression of these genes mostly returned to levels found in mock-inoculated plants by 24 hai. In the susceptible genotype, gene expression remained unaffected by rust infection until 96 hai, a time period when rapid fungal growth began. In contrast, gene expression in the resistant genotype diverged from the mock-inoculated control earlier, at $72 \mathrm{~h}$, demonstrating that Rpp2-mediated defenses were initiated prior to this time. These data suggest that ASR initially induces a nonspecific response that is transient or is suppressed when early steps in colonization are completed in both soybean genotypes. The race-specific resistance phenotype of $R p p 2$ is manifested in massive gene expression changes after the initial response prior to the onset of rapid fungal growth that occurs in the susceptible genotype.
\end{abstract}

Additional keywords: compatible, incompatible, microarray, obligate biotroph, transcriptome.

Corresponding authors: Steven A. Whitham or Thomas J. Baum; Fax: +1515-294-9420, E-mail: swhitham@iastate.edu or tbaum@iastate.edu.

Microarray data are available as follows. The GeneChip Soybean Genome Array raw and normalized data files were deposited in the ArrayExpress database under accession number E-TABM-230 and raw data files in the Plant Expression Database under accession number GM2, both MIAMEcompliant databases, along with the appropriate protocols.

The Spotlight logo represents articles that, in the opinion of the senior editor and editor-in-chief, are of special interest to a broad readership.

* The $e$-Xtra logo stands for "electronic extra" and indicates that supplemental material is available online. Three additional tables are published online.
Phakopsora pachyrhizi is an obligate biotrophic plant-pathogenic fungus that is commonly known as Asian soybean rust (ASR). ASR colonizes leaf tissue and, to a lesser extent, stems and pods (Miles et al. 2006). Under favorable conditions, infection can result in yield losses ranging from $10 \%$ during mild disease pressure to $80 \%$ during severe epidemics (Bromfield 1984; Ogle et al. 1979; Patil et al. 1997). To date, four major ASR resistance $(R)$ genes have been described, but none of them have been cloned (Rppl [Cheng and Chan 1968; Hidayat and Somaatmadja 1977], Rpp2 [Hidayat and Somaatmadja 1977], Rpp3 [Bromfield and Hartwig 1980; Singh and Thapliyal 1977]. and Rpp4 [Hartwig 1986]). The effectiveness of these $R$ genes is limited by virulent ASR isolates that are able to overcome each of them (Bonde et al. 2006; Miles et al. 2006). For this reason, the use of genetic resistance has not yet been successful and the only control method is the timely application of fungicides. Incompatible interactions mediated by Rppl have an immune phenotype (Miles et al. 2006), whereas resistances conferred by the other three $R$ genes are characterized by limited fungal growth and sporulation and the formation of reddish-brown lesions (Bonde et al. 2006). Compatible interactions typically are characterized by tan-colored lesions with fully sporulating uredinia (Bromfield 1984; Bromfield and Hartwig 1980; Miles et al. 2006).

The typical ASR lifecycle begins when asexual urediniospores germinate and form a germ tube within 1 to $2 \mathrm{~h}$ after inoculation (hai) when incubated in a dark, humid environment at conducive temperatures (Bonde et al. 1976). The tips of germ tubes then swell to form appressoria over anticlinal walls of epidermal cells within 2 hai (Bonde et al. 1976; Koch et al. 1983). An appressorial cone forms inside the appressorium by 7 hai and then a penetration hypha directly traverses the epidermal cell. When the penetration hypha emerges into the intercellular space below the epidermal cell, a septum is formed by 15 to 20 hai, producing a primary hypha (Koch et al. 1983; Sato and Sato 1982). The penetrated epidermal cell loses cellular organization within 24 hai and collapses by 4 days after inoculation (dai) (Koch et al. 1983; Yang 1991). The primary hyphae grow between spongy mesophyll cells and occasionally form haustorial mother cells that give rise to globose haustoria (i.e., the specialized organs that form between the plant cell wall and plasma membrane through which the fungus obtains nutrients and secretes effector proteins (Hahn et al. 1997; Staples 2000, 2001; Voegele and Mendgen 2003). The first haustoria typically are formed between 24 and 48 hai (Koch et al. 1983; Yang 1991). Upon successful completion of these events, the fungus proceeds to further colonize the intercellular spaces of 
the spongy mesophyll by producing secondary hyphae and additional haustoria (Yang 1991). Hyphae aggregate to form uredinial primordia in which urediniospores differentiate at 7 to 9 dai (Marchetti et al. 1975). Urediniospores are released by rupture of the epidermis at 9 dai and uredinia will actively disseminate urediniospores for up to 4 weeks (Koch et al. 1983; Marchetti et al. 1975). Microscopic analyses of ASR infection have suggested that the timing of early disease events is similar in susceptible and Rpp2-resistant soybean genotypes up to 2 dai (Hoppe and Koch 1989). After 2 dai, mycelial development was associated with localized host cell death, resulting in collapse of adjacent fungal hyphae in the Rpp2 genotype (Hoppe and Koch 1989). Because of this host response, development of uredinia on resistant soybean lines is delayed and uredinia senesce 2 to 4 days earlier than in fully susceptible genotypes (Marchetti et al. 1975; McLean 1979).

Although microscopic studies have carefully detailed the infection and development of ASR within resistant and susceptible soybean genotypes, there currently is very little information about the molecular events of the compatible and incompatible interactions. As a starting point for understanding key molecular mechanisms that underlie ASR disease and defense, we designed an experimental approach to determine the effects of ASR infection on the abundance of soybean mRNAs in both susceptible and resistant genotypes using the GeneChip Soybean Genome Array. Sampling time points were chosen to coincide with the events of ASR infection that were outlined above in order to correlate host gene expression with crucial stages of fungal infection in the Rpp2-resistant genotype PI230970 and the highly susceptible genotype Embrapa-48.

\section{RESULTS}

\section{Experimental design and verification of ASR infection.}

To assess soybean gene expression in resistant (PI230970, Rpp2) and susceptible (Embrapa-48) plants, RNA was extracted from leaves of two plants that had been inoculated with an ASR urediniospore suspension or a mock solution without spores. mRNA profiling was conducted at $6,12,18,24,36,48$, $72,96,120$, and 168 hai, spanning ASR development up to the formation of uredinia. The appearance of reddish-brown lesions on the underside of resistant leaves (Fig. 1A) and similar numbers of tan-colored lesions on susceptible leaves (Fig. 1B) confirmed the phenotypes expected for the compatible and incompatible interactions, respectively. Successful fungal in- fection also was verified by measuring the abundance of a constitutively expressed ASR $\alpha$-tubulin mRNA in the RNA samples over time (Fig. 2). Quantitative reverse-transcriptase polymerase chain reaction (qRT-PCR) assays demonstrated that similar quantities of ASR $\alpha$-tubulin transcripts were present in Embrapa-48 and PI230970 up through 96 hai. Beginning at 120 hai, the ASR $\alpha$-tubulin transcript abundance dramatically increased in the susceptible genotype, indicating prolific fungal growth and colonization. In contrast, the ASR $\alpha$-tubulin transcript increased only moderately after 96 hai in Rpp2 leaves, confirming a successful resistance response. These results demonstrate that ASR infection was successful in this experiment and that the selected soybean genotypes had the expected ASR infection phenotypes.

\section{Biphasic expression of soybean genes in response to ASR.}

The abundance of soybean mRNAs was assayed using the GeneChip Soybean Genome Array, which contains $>37,500$ probe sets representing 35,611 soybean transcripts. Each probe

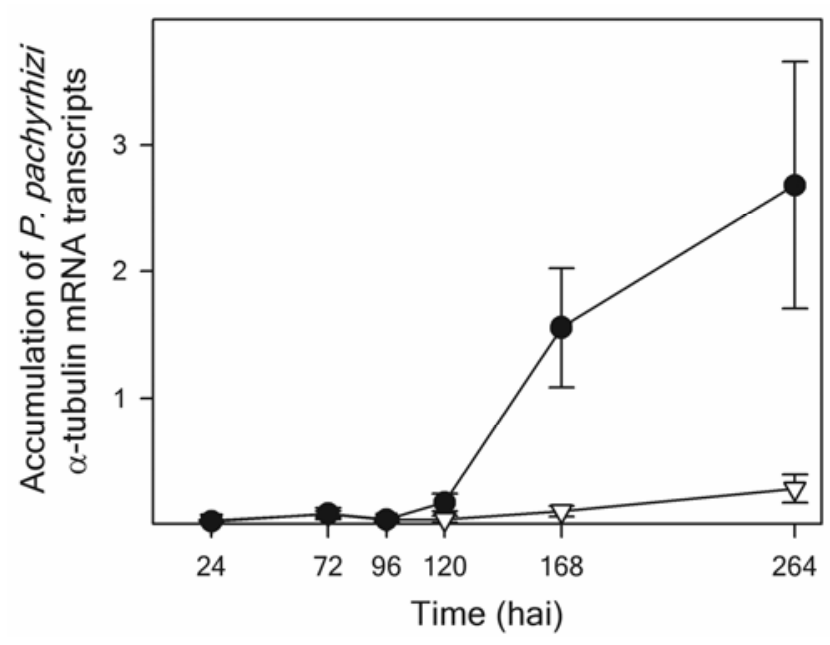

Fig. 2. Differential accumulation of Asian soybean rust (ASR) $\alpha$-tubulin mRNA transcripts in susceptible $(\bigcirc)$ and resistant $(\nabla)$ soybean leaves (mean \pm standard error of the mean, $n=3$ ). Transcript levels of Phakopsora pachyrhizi $\alpha$-tubulin in ASR-infected leaves during the infection time course and plotted relative to soybean ubiquitin-3 expression levels as determined by quantitative reverse-transcriptase polymerase chain reaction; hai $=\mathrm{h}$ after inoculation.
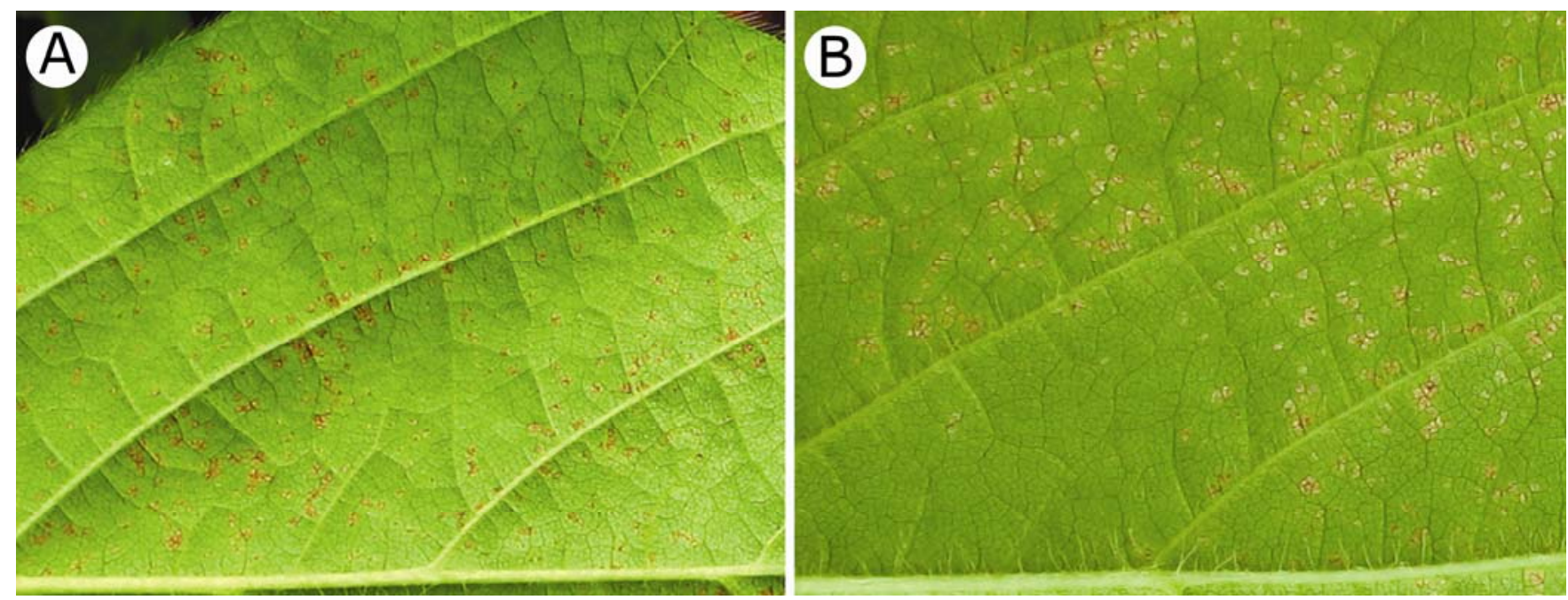

Fig. 1. Asian soybean rust lesions on the underside of soybean leaves at $168 \mathrm{~h}$ after inoculation. A, Reddish-brown lesions on resistant PI230970 leaves carrying the Rpp2 gene. B, Tan lesions on susceptible Embrapa-48 leaves. 
set is made up of 11 individual oligonucleotide probes, and $89 \%$ of these probe sets hybridize specifically to a unique sequence in the soybean genome. Therefore, the majority of probe set hybridization results represent mRNA abundance corresponding to individual soybean genes.

All data obtained in this study were deposited in the ArrayExpress database (accession number E-TABM-230) (Parkinson et al. 2007) and the Plant Expression database (PLEXdb, accession number GM2) (Wise et al. 2007). The data from infected samples from each genotype were analyzed with respect to their corresponding mock-inoculated samples. A linear model statistical analysis used to identify significant mRNA abundance changes revealed 1,516 and 894 probe sets at the $5 \%$ false discovery rate (FDR) $(q \leq 0.05$ derived from $P$ values $<$ 0.0025 ) in susceptible and resistant plants, respectively (Supplementary Tables 1 and 2). More detail on our linear model analysis is provided below and by Nettleton (2006). At the 5\% FDR, 470 probe sets identified significant gene expression changes in both genotypes, whereas 1,046 and 424 probe sets were unique to either the susceptible or the resistant genotypes, respectively. The probe sets that are unique to each genotype do not necessarily represent genes that change expression only in resistant or susceptible responses. In order to maintain the FDR at $5 \%$, it is inevitable that some truly differentially expressed genes will go undetected in each comparison.
To visualize how expression of these genes was affected by ASR infection, we performed a hierarchical clustering analysis of the 470 probe sets that changed expression following ASR infection in both genotypes at the 5\% FDR (Fig. 3). This analysis indicated that differential gene expression peaked within 12 hai in both genotypes. By 24 hai, few of the genes were expressed differently from the noninoculated controls in either genotype. However, a second phase of strong differential soybean gene expression was observed in both genotypes at later stages of infection, which started earlier in the resistant genotype than in the susceptible genotype.

To validate this observation of biphasic differential gene expression statistically, we performed separate linear model analyses by time frame. The number of ASR-responsive probe sets at the 5\% FDR was determined in early infection (germination and penetration from 6 to 36 hai), middle infection (haustoria formation and initial growth of intercellular, secondary hyphae from 36 to 72 hai), and late infection (colonization, lesion or uredinia formation from 72 to 168 hai) (Fig. 4). Because this statistical analysis is different from the whole time course analysis described above, the total numbers of genes identified cannot be expected to be the same. Consistent with the results obtained by hierarchical clustering, many ASR-responsive genes were differentially regulated during early infection, with 879 probe sets in the susceptible genotype

Table 1. Gene ontology (GO) biological process classification of Asian soybean rust (ASR)-regulated probe sets on the Soybean Genome Array and overrepresented biological processes as determined by Fisher exact test

\begin{tabular}{|c|c|c|c|}
\hline \multirow[b]{2}{*}{ GO biological process description } & \multirow[b]{2}{*}{ Probe sets ${ }^{\mathbf{b}}$} & \multicolumn{2}{|c|}{$\begin{array}{l}\text { No. of ASR-responsive probe sets } \\
\text { (adjusted } P \text { value for multiple testing) }\end{array}$} \\
\hline & & Embrapa-48 & PI230970 \\
\hline \multicolumn{4}{|l|}{ I. Defense or stress responses } \\
\hline \multicolumn{4}{|l|}{ Ia. Responses to biotic stress } \\
\hline Defense response (GO:0006952) & 358 & $39(0) *$ & $23(0.016) *$ \\
\hline Response to biotic stimulus (GO:0009607) & 18 & $7(0.003) *$ & $5(0.041) *$ \\
\hline Response to fungus (GO:0009621) & 39 & $15(0) *$ & $12(0) *$ \\
\hline Response to other organism (GO:0042828) & 65 & $18(0) *$ & $13(0) *$ \\
\hline Defense response to bacterium (GO:0042830) & 16 & $5(0.263)$ & $5(0.022) *$ \\
\hline Defense response to bacterium, incompatible interaction (GO:0009816) & 62 & $11(0.028) *$ & $6(2.898)$ \\
\hline \multicolumn{4}{|l|}{ Ib. Responses involving hormone signaling } \\
\hline Response to jasmonic acid stimulus (GO:0009753) & 266 & $35(0) *$ & $29(0) *$ \\
\hline Response to salicylic acid stimulus (GO:0009751) & 189 & $28(0) *$ & $25(0) *$ \\
\hline Systemic acquired resistance, salicylic acid-mediated signaling pathway (GO:0009862) & 23 & $8(0.002) *$ & $8(0) *$ \\
\hline \multicolumn{4}{|l|}{ Ic. Other stress responses } \\
\hline Response to wounding (GO:0009611) & 216 & $27(0) *$ & $25(0) *$ \\
\hline Somatic embryogenesis (GO:0010262) & 5 & $4(0.011) *$ & $4(0.001) *$ \\
\hline Response to oxidative stress (GO:0006979) & 214 & $23(0.017) *$ & $14(0.539)$ \\
\hline \multicolumn{4}{|l|}{ II. Secondary metabolism } \\
\hline Flavonoid biosynthetic process (GO:0009813) & 79 & $22(0) *$ & $25(0) *$ \\
\hline Chalcone biosynthetic process (GO:0009715) & 17 & $10(0) *$ & $10(0) *$ \\
\hline Regulation of anthocyanin biosynthetic process (GO:0031540) & 18 & $10(0) *$ & $10(0) *$ \\
\hline Lignan biosynthetic process (GO:0009807) & 20 & $10(0) *$ & $9(0) *$ \\
\hline Lignin biosynthetic process (GO:0009809) & 80 & $10(1.154)$ & $10(0.016) *$ \\
\hline Camalexin biosynthetic process (GO:0010120) & 4 & $3(0.21)$ & $4(0) *$ \\
\hline Indole glucosinolate biosynthetic process (GO:0009759) & 9 & $3(3.782)$ & $4(0.03) *$ \\
\hline \multicolumn{4}{|l|}{ III. Transport } \\
\hline Electron transport (GO:0006118) & 761 & $65(0) *$ & $48(0) *$ \\
\hline Ammonium transport (GO:0015696) & 4 & $2(7.629)$ & $3(0.043) *$ \\
\hline Auxin polar transport (GO:0009926) & 70 & $11(0.089)$ & $10(0.005) *$ \\
\hline Carbohydrate transport (GO:0008643) & 71 & $12(0.021) *$ & $8(0.23)$ \\
\hline Lead ion transport (GO:0015692) & 18 & $6(0.043) *$ & $3(6.899)$ \\
\hline \multicolumn{4}{|l|}{ IV. Transcription and regulation } \\
\hline Regulation of transcription, DNA-dependent (GO:0006355) & 914 & $45(142.404)$ & $57(0) *$ \\
\hline Protein amino acid phosphorylation (GO:0006468) & 1,120 & $76(0.011) *$ & $48(0.075)$ \\
\hline \multicolumn{4}{|l|}{ V. Miscellaneous } \\
\hline Fatty acid $\alpha$-oxidation (GO:0001561) & 6 & $4(0.031) *$ & $5(0) *$ \\
\hline Lipid metabolic process (GO:0006629) & 218 & $17(7.254)$ & $17(0.017) *$ \\
\hline Response to gravity (GO:0009629) & 18 & $10(0) *$ & $10(0) *$ \\
\hline Toxin catabolic process (GO:0009407) & 57 & $12(0.002) *$ & $10(0.001) *$ \\
\hline
\end{tabular}

\footnotetext{
${ }^{a}$ Embrapa-48 and PI230970 $=$ susceptible and resistant plants, respectively. Asterisk $(*)$ represents statistical significance $(P$ value $\leq 0.05)$.

${ }^{\mathrm{b}}$ Total probe sets in category on the GeneChip.
} 
and 240 in the resistant genotype at the 5\% FDR. During midinfection, only 16 and 5 probe sets were expressed at significantly different levels in infected tissue compared with the mock in the susceptible and resistant plants, respectively. In the late stages of infection, gene expression in infected plants again diverged significantly from the mock control, and 180 and 238 ASR-regulated probe sets were identified in the susceptible and resistant genotypes, respectively.

In-depth analyses of the hierarchical clustering analysis of the 470 probe sets that changed expression following ASR infection in both genotypes (Fig. 3) revealed that there were temporal differences in gene expression between the two genotypes at the late infection time frame. Through 48 hai, the expression profiles of the 470 common ASR-regulated probe sets were very similar. However, the two genotypes had distinct differences in the expression of these genes beginning at the 72 hai time point. At this time, the majority of the genes were induced in the resistant genotype, whereas they were not induced in the susceptible genotype until 96 hai. To quantify this observation, we performed hierarchical cluster analyses of these 470 probe sets specifically on the early (6 to 36 hai) and late (72 to 168 hai) infection time frames (Supplementary Table 3 ). This analysis placed each of the 470 common probe sets into one of 25 clusters with distinct expression profiles. At the 6 to 36 hai time frame, $62 \%$ of the probe sets were placed into the same cluster in each of the two genotypes, demonstrating that these probe sets had similar expression profiles. In contrast, only $6 \%$ of the common probe sets had similar expression profiles over the 72 to 168 hai time frame. These findings confirm that there are distinct biphasic responses over time to ASR in the resistant and susceptible genotypes.

\section{Functional annotation of ASR-regulated genes.}

The functional annotation of the ASR-regulated gene list was retrieved from the SoyBase website, which also supplies probe set matches to homologous Arabidopsis genes, including the associated gene ontology (GO) terms ( $\mathrm{E}$ value $\leq 10^{-4}$; discussed below). Fisher's exact test was used to obtain an overview of GO functional classes that were significantly over- or underrepresented in the gene lists from the resistant and susceptible genotypes (Drăghici et al. 2003; Fisher 1966). This analysis revealed that, in both soybean genotypes, the GO functional classes of defense responses, secondary metabolism, transcription and regulation, and transport were overrepresented (Table 1). In the resistant genotype, uniquely overrepresented genes be- longed to the transcription functional class. On the other hand, underrepresented functional classes (i.e., those genes that change gene expression less frequently than expected to occur at random) included the GO functional class of translation.

At least one gene representative of the GO functional classes defense responses, secondary metabolism, transcription and regulation, transport, and unknown categories was selected for qRT-PCR. The fold changes determined for each of these genes by qRT-PCR and microarray analysis are shown for 12 and 168 hai in Table 2 for both the susceptible and resistant soybean genotypes. The qRT-PCR-determined fold change of the selected qRT-PCR target genes generally was congruent to the microarray-determined gene expression changes.

\section{Secondary metabolism.}

Because the statistical analysis of functional classes showed an overrepresentation of genes associated with secondary metabolism (Table 1), we examined the flavonoid biosynthetic pathways that are involved in plant defense responses through production of various phytoalexins and cell wall-reinforcing metabolites (Hahlbrock and Scheel 1989; La Camera et al. 2004). In general, the expression of these genes increased significantly during early infection in both soybean genotypes. However, by 24 hai, the expression of most genes had returned to mock control levels (i.e., no differential gene expression) (Fig. 5). Later in infection, gene expression diverged again, but with distinct kinetics in the two interaction types. The increased expression of these genes occurred at least 1 day earlier in resistant plants compared with the susceptible plants (Fig. 5). The profiles of these flavonoid biosynthetic genes are consistent with the general finding that differential gene expression occurred primarily in the early and late stages of ASR infection (Fig. 4).

\section{Differential expression of transcription factors.}

The overrepresentation of transcription factor genes in gene lists from resistant plants led us to further investigate their identities and expression profiles in both interaction types (Table 3 ). We found that 127 probe sets corresponding to transcription factors are differentially regulated in ASR-infected leaves, and over half (70) of these transcription factor probe sets belong to classes associated with defense and stress responses (Rushton and Somssich 1998; Singh et al. 2002). Interestingly, 46 of these defense-associated transcription factor probe sets belong to the WRKY class of transcription factors, indicating the importance of these proteins in the response to ASR infec-

Table 2. Comparison of fold change of selected probe sets as determined by microarray analysis and quantitative reverse-transcriptase polymerase chain reaction $(\mathrm{qRT}-\mathrm{PCR})^{\mathrm{a}}$

\begin{tabular}{|c|c|c|c|c|c|}
\hline \multirow[b]{2}{*}{ Probe set tested, annotation } & \multirow[b]{2}{*}{ Method $^{b}$} & \multicolumn{2}{|c|}{ Susceptible genotype } & \multicolumn{2}{|c|}{ Resistant genotype } \\
\hline & & 12 hai & 168 hai & 12 hai & 168 hai \\
\hline \multirow[t]{2}{*}{ Gma.3713.1.S1_s_at (Q1SV12), Kunitz inhibitor ST1-like } & $\mathrm{q}$ & $0.94 \pm 0.44$ & $2.74 \pm 0.59$ & $1.04 \pm 0.24$ & $1.18 \pm 0.37$ \\
\hline & $\mathrm{M}$ & $-0.18 \pm 0.16$ & $4.82 \pm 0.69$ & $-0.09 \pm 0.03$ & $3.57 \pm 0.63$ \\
\hline \multirow[t]{2}{*}{ GmaAffx.4296.1.S1_at, unknown protein } & $\mathrm{q}$ & $1.58 \pm 0.1$ & $2.14 \pm 0.71$ & $0.9 \pm 0.26$ & $1.39 \pm 0.21$ \\
\hline & M & $1.65 \pm 0.16$ & $1.94 \pm 0.6$ & $0.94 \pm 0.17$ & $1.22 \pm 0.18$ \\
\hline \multirow[t]{2}{*}{ GmaAffx.4552.1.S1_s_at (Q9FX14), unknown protein } & $\mathrm{q}$ & $0.85 \pm 0.11$ & $4.99 \pm 0.83$ & $1.31 \pm 0.37$ & $4.26 \pm 0.31$ \\
\hline & M & $0.91 \pm 0.21$ & $5.52 \pm 0.2$ & $3.07 \pm 0.67$ & $3.77 \pm 0.63$ \\
\hline \multirow[t]{2}{*}{ GmaAffx.46129.1.S1_at (Q85V22), histidine amino acid transporter } & $\mathrm{q}$ & $0.1 \pm 0.14$ & $0.18 \pm 0.85$ & $0.47 \pm 0.22$ & $0.11 \pm 0.37$ \\
\hline & M & $3.08 \pm 0.56$ & $4.39 \pm 0.85$ & $3.17 \pm 1.07$ & $2.32 \pm 0.36$ \\
\hline \multirow[t]{2}{*}{ GmaAffx.46214.4.S1_at (P43309), polyphenol oxidase } & $q$ & $0.94 \pm 0.44$ & $2.74 \pm 0.59$ & $1.04 \pm 0.24$ & $1.18 \pm 0.37$ \\
\hline & M & $3.12 \pm 0.47$ & $3.54 \pm 0.76$ & $2.11 \pm 0.4$ & $2.38 \pm 0.12$ \\
\hline \multirow{3}{*}{$\begin{array}{l}\text { GmaAffx.69949.1.S1_at (Q9XED4), receptor-like protein kinase } \\
\text { homolog RK20-1 }\end{array}$} & & & & & \\
\hline & $\mathrm{q}$ & $2.89 \pm 0.78$ & $6.71 \pm 1.37$ & $2.67 \pm 0.33$ & $4.45 \pm 0.37$ \\
\hline & M & $3.61 \pm 0.63$ & $7.21 \pm 0.84$ & $2.43 \pm 0.31$ & $4.28 \pm 0.64$ \\
\hline \multirow[t]{2}{*}{ GmaAffx.91194.1.S1_at (Q96570), L-lactate dehydrogenase } & $\mathrm{q}$ & $1.27 \pm 0.31$ & $1.6 \pm 0.57$ & $0.74 \pm 0.15$ & $0.84 \pm 0.37$ \\
\hline & M & $1.16 \pm 0.38$ & $1.87 \pm 0.66$ & $0.59 \pm 0.13$ & $0.86 \pm 0.46$ \\
\hline
\end{tabular}

\footnotetext{
${ }^{\mathrm{a}}$ Hours after inoculation $=$ hai.

${ }^{b}$ Method by which the fold change was derived: $\mathrm{M}=$ microarray experiment and $\mathrm{q}=\mathrm{qRT}-\mathrm{PCR}$.
} 
tion. In all, 127 probe sets on the Soybean Genome Array were assigned to the WRKY transcription factor family, and approximately one-third (46) of them are differentially regulated at the mRNA level in response to ASR. Of the 46 ASR-regulated WRKY probe sets, 24 changed expression significantly in both the compatible and incompatible interaction, whereas gene expression changes in 18 probe sets were significant in the incompatible interaction and only 4 ASR-regulated WRKY probe sets changed significantly in the compatible interaction.

Several WRKY transcription factors are differentially regulated in other host-pathogen interactions, and play important roles in mediating host defense responses (Eulgem 2005; Wang et al. 2005; Zhang and Wang 2005). Therefore, we further investigated the expression profiles of these 46 WRKY transcription factor probe sets by hierarchical clustering (Fig. 6). This analysis shows that several of the WRKYs have expression profiles consistent with other defense and secondary metabolism genes, because they were induced at the early time frame and subsequently returned to mock levels. The expression again diverged from mock later in infection and approximately 1 day earlier in the resistant plants than in the susceptible plants. In addition, some WRKY transcription factors show the opposite of this profile by being downregulated early in infection and returning to mock levels before being downregulated again later in infection, whereas some others appear to be constitutively induced or repressed during ASR infection. These upand downregulated WRKY transcription factors suggest complex positive and negative regulation of soybean defense pathways that will be important to investigate further through functional assays (Fig. 6).

\section{DISCUSSION}

Time course analysis identifies biphasic soybean responses to ASR infection.

To assess the effects of ASR infection on the soybean transcriptome, we infected resistant (Rpp2) and susceptible soybean plants with $P$. pachyrhizi. Successful infection was verified by the appearance of visual symptoms on inoculated plants from 6 through 11 dai (Fig. 1). In addition, fungal $\alpha$-tubulin mRNA transcripts were quantified from 2 dai through 11 dai (Fig. 2). Similar accumulation of ASR $\alpha$-tubulin mRNA was detected in both interaction types through 96 hai, followed by a dramatic increase in the susceptible genotype at 5 dai and continuing through 11 dai. This was in contrast to the modest increase in ASR $\alpha$-tubulin mRNA accumulation that occurred in the resistant plants through 11 dai, which showed that Rpp2-mediated defense mechanisms were successful in reducing the rate of fungal colonization and proliferation. The slow increase in the

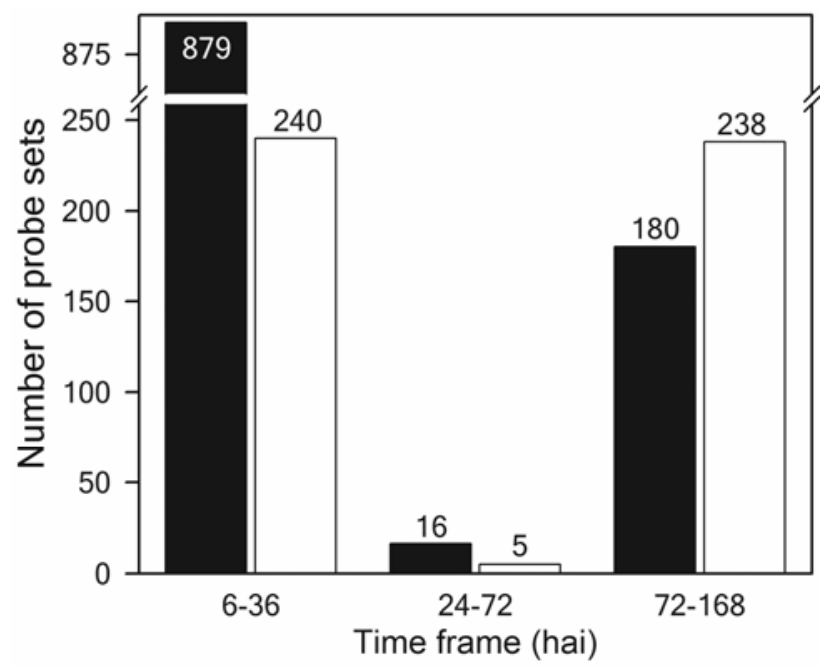

Fig. 4. Biphasic responses of soybean to Asian soybean rust (ASR). Number of significant probe sets that respond to ASR in the susceptible (solid bars) and resistant genotype (open bars) in early (6 to $36 \mathrm{~h}$ after inoculation [hai]), middle ( 24 to 72 hai), and late stages (72 to 168 hai) of ASR infection ( $5 \%$ false discovery rate).

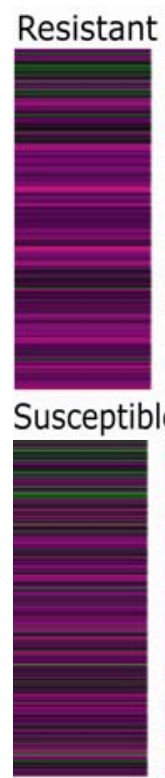

6
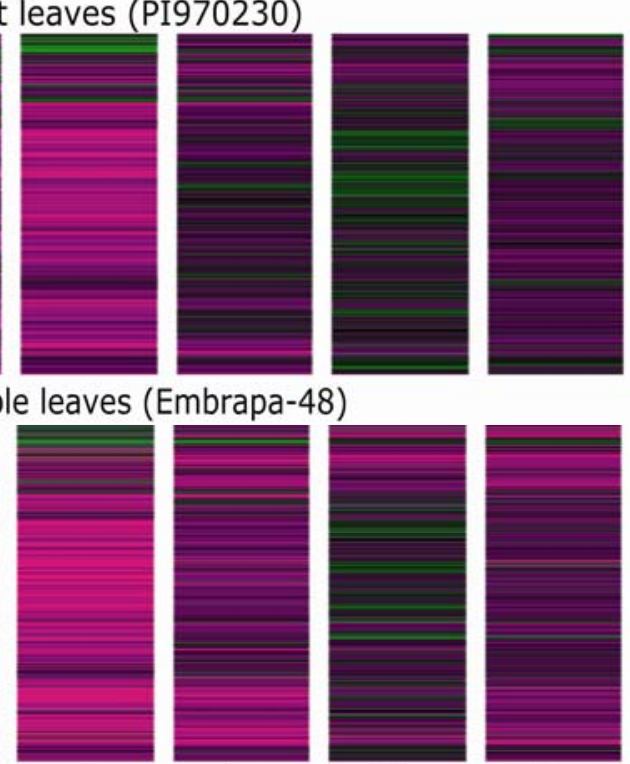

12

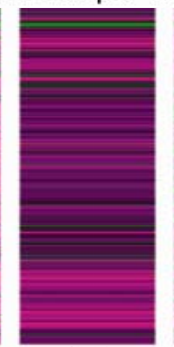

18

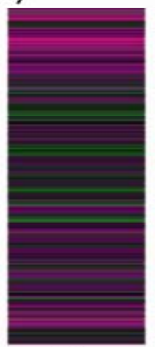

24

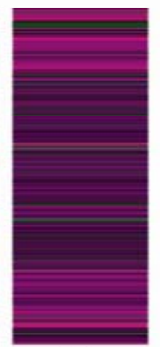

36
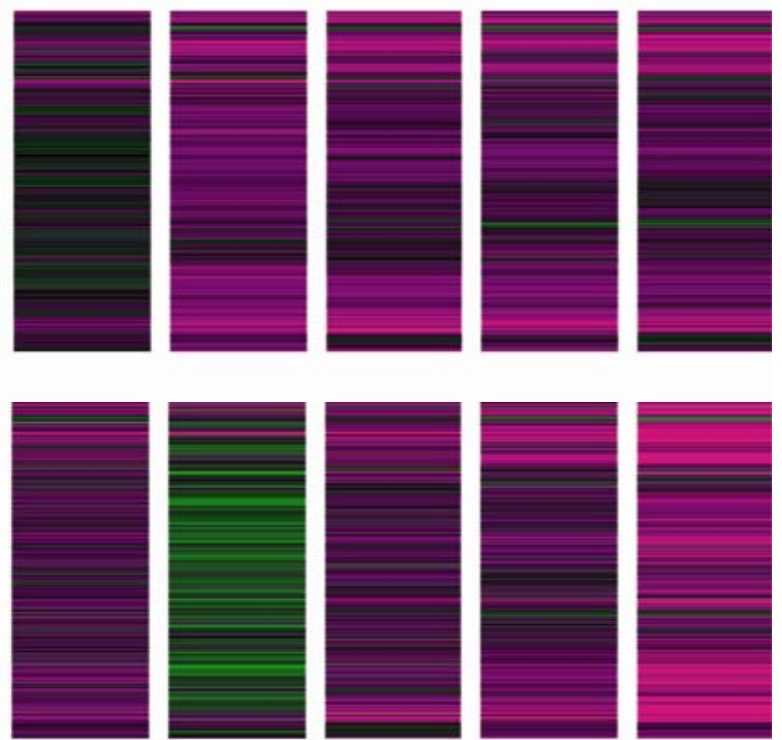

48

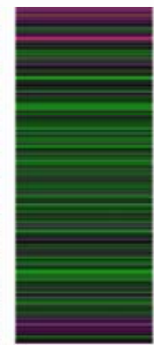

72

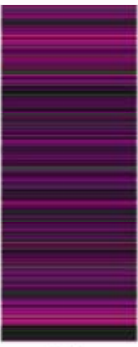

96

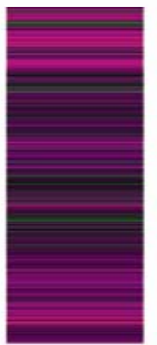

120

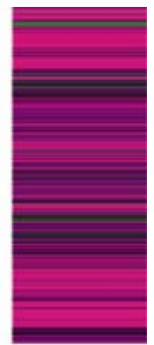

168

Fig. 3. Changes in soybean gene expression during early and late infection stages demonstrate a biphasic response to Asian soybean rust (ASR). Hierarchical clustering was used to group the 470 ASR-regulated probe sets identified in common to both susceptible and resistant genotypes at the $5 \%$ false discovery rate. Each of the 470 rows represents a probe set on the Soybean Genome Array and each column represents the indicated sampling time. Black boxes represent no change in gene expression compared with the uninfected mock treatment, magenta indicates upregulation, and green indicates downregulation. More intense colors represent greater fold change. 
accumulation of fungal $\alpha$-tubulin mRNA transcripts in Rpp2 plants was consistent with the reduced amounts of uredinia per lesion, reduced number of spores produced per uredinium, later maturity of uredinia, and earlier senescence that have been reported previously (Bonde et al. 2006; Bromfield 1984). Thus, in our experiment, ASR made a developmental transition between 96 and 120 hai from slow growth to rapid proliferation within leaves of the susceptible host that was prevented in the Rpp2 plants. Similar results recently were reported for poplar rust, yet differential rust accumulation in this pathosystem was observed starting at 48 hai (Rinaldi et al. 2007).

As with the pattern of fungal growth, the expression of soybean genes was similar in the resistant and susceptible plants during early infection. Gene expression in the two interaction types diverged later in the time course, beginning at approximately 72 hai. The onset of differential gene expression was approximately 1 to 2 days earlier in the resistant plants than in the susceptible plants relative to their respective mock-inoculated controls. These data demonstrate that differential gene expression occurred between the two interaction types as expected. In addition, these results indicate that Rpp2 mediates the recognition of this ASR isolate some time prior to 72 hai. Hierarchical cluster analysis supported the observation that many ASR-regulated genes respond early during the infection (6 to 36 hai), followed by a period (24 to 72 hai) in which expression levels return to mock levels,

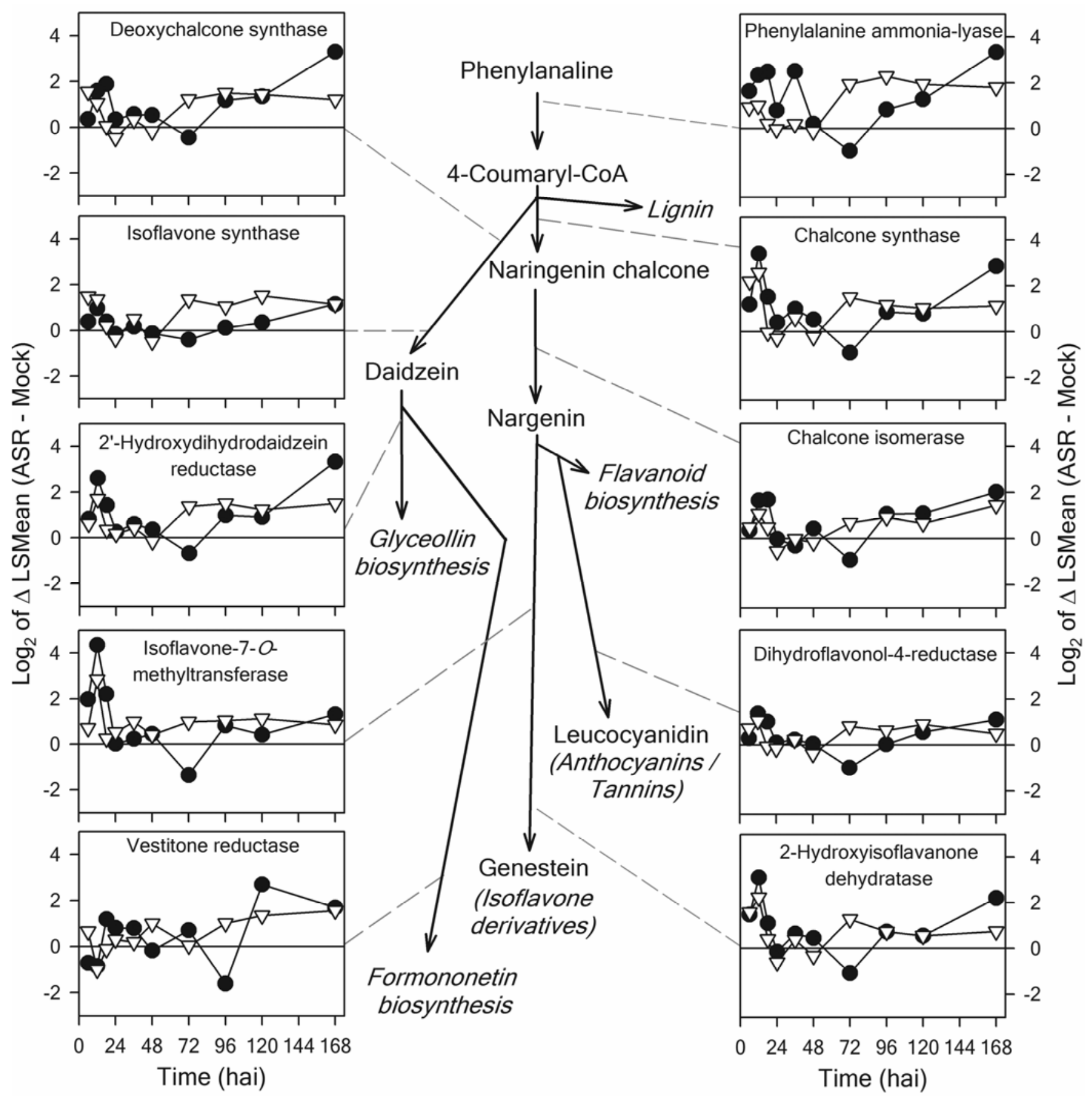

Fig. 5. Expression profiles of selected genes in the flavonoid biosynthetic pathway in susceptible $(\bullet)$ and resistant $(\nabla)$ leaves. Asian soybean rust infection leads to an induction of the major flavonoid pathways as highlighted by the accompanying differential expression profiles of selected genes whose enzyme products catalyze product conversions; hai $=\mathrm{h}$ after inoculation . 
and a new divergence in gene expression during late infection (72 to 168 hai). The conclusions from this pattern analysis were validated when the statistical analysis was broken down into early, intermediate, and late time frames. This analysis demonstrated that most genes with differential expression patterns were significantly induced early in the infection process. During the intermediate time points, only very few genes were differentially expressed in either genotype relative to mock-inoculated plants. A second round of major gene expression changes occurred later in infection in both the resistant and susceptible genotypes.

Compatible soybean-pathogen interactions involving Phytophthora sojae, soybean cyst nematode, and Pseudomonas syringae pv. glycinea also provide evidence for early defenselike responses to pathogen infection (Alkharouf et al. 2006; Ithal et al. 2007; Moy et al. 2004; Zabala et al. 2006; Zou et al. 2005). Similarities in the expression profiles of host genes at very early stages of compatible and incompatible interactions also have been observed in other fungus-plant interactions. Caldo and associates (2004) performed a time course analysis of compatible and incompatible interactions between barley and barley powdery mildew (Blumeria graminis f. sp. hordei). Over the first 16 hai, the authors observed similar gene expression profiles in the compatible and incompatible interactions. At subsequent time points, the expression profiles of many genes diverged, with further induction or constant expression in the incompatible interactions but with reduced expression in the compatible interaction. The timing of this divergence corresponded with the well-established kinetics of haustoria formation by B. graminis f. sp. hordei (Caldo et al. 2004). Boddu and associates (2006) infected barley spikes with Fusarium graminearum and profiled barley mRNA from 24 to 144 hai. In this compatible interaction, differential expression of host genes beginning at 48 hai generally was observed. It would be interesting to know whether $F$. graminearum also induces transient changes in host gene expression within the first 24 hai, as observed in our study.

The early responses to ASR that occur in both interaction types suggest a nonspecific recognition of ASR and activation of basal soybean defenses. This nonspecific recognition may be activated by microbe-associated molecular patterns (MAMPs) (Mackey and McFall 2006) that mediate activation of basal defenses, which has been described in other systems (Alkharouf et al. 2006; Bernardo et al. 2007; Caldo et al. 2004; Iqbal et al. 2005; Moy et al. 2004; Pritsch et al. 2000). Examples of potential MAMPs presented to the soybean plant include chitin fragments or other molecules of fungal origin that are generated by hydrolytic plant enzymes (Baureithel et al. 1994; Kaku et al. 2006; Mithöfer et al. 2000; Shibuya et al. 1993; Yamaguchi et al. 2000). Another set of potential nonspecific signals may be derived from the activities of the fungus on the plant cell wall as it penetrates through and kills epidermal cells in both interaction types. Signals generated as a result of this action might include hydrolytic products of the plant cell wall generated by fungal hydrolases or by action of plant defensive enzymes (Bruce and West 1982; Davis and Hahlbrock 1987; Enkerli et al. 1999; Ron and Avni 2004; Ryan et al. 1986). Signals emanating from these epidermal cells may influence the response of neighboring plant cells, as has been observed in powdery mildew infection of cereals. B. graminis f. sp. tritici infection of wheat caused increased expression of defenserelated transcripts in mesophyll cells bordering infected epidermal cells (Bruggmann et al. 2005). Gjetting and associates (2007) studied gene expression in B. graminis f. sp. hordeiinfected barley epidermal cells and neighboring noninfected epidermal cells and showed that both cell types responded to pathogen infection at 18 hai.
Lack of differential soybean gene expression at intermediate stages of ASR infection.

A fascinating aspect of this study is the quenching of divergent expression of ASR-regulated genes in both host genotypes during the intermediate stages of ASR infection. The expression of nearly all host genes that were differentially regulated at the early time frame returns to mock-inoculated levels by 24 hai. This low level of activity lasts for 3 days in the susceptible plants and corresponds to time points at which ASR $\alpha$-tubulin mRNA accumulation remains at a relatively low level (Fig. 2). It seems unlikely that low fungal growth is sufficient to explain the lack of host responses during this period of time, because ASR has been reported to form haustoria between 24 and 48 hai and to begin establishing secondary hyphae (Koch et al. 1983; Sato and Sato 1982; Yang 1991). Therefore, the formation of haustoria would result in numerous host cells in a leaf with significant direct interactions with ASR during this period.

Another plausible explanation for the lack of differential gene expression at the intermediate time frame is that ASR actively inhibits the early host responses in both of the interaction types. Haustorium-forming fungi and oomycetes secrete many proteins during the parasitic stage of host infection, both inside the extrahaustorial matrix and inside the plant cell (Catanzariti et al. 2007). Presumably, these proteins enable these pathogens to obtain nutrients, to direct host responses, or to avoid being detected by the host (Birch et al. 2006; Ellis et al. 2006; Voegele and Mendgen 2003). In incompatible interactions, detection of some of these effectors (Avr proteins) is believed to occur by either direct (receptor-ligand model) or indirect recognition (guard hypothesis) by a specific host $\mathrm{R}$ protein, which generally triggers a rapid activation of host defenses (Dangl and Jones 2001). Secreted proteins from flax rust (AvrL567) (Dodds et al. 2004) and broad bean rust (RTP1) (Kemen et al. 2005) are delivered directly into host cells through the extrahaustorial membrane. The oomycete Phytophthora also forms haustoria and secretes molecular signals, some of which are targeted to the host cytoplasm, to reprogram molecular host defenses (Birch et al. 2006). The response of resistant plants at 72 hai suggests that the elicitor of Rpp2-mediated resistance is

Table 3. Transcription factors present in Asian soybean rust (ASR) gene lists for susceptible and resistant genotype

\begin{tabular}{lcc}
\hline Transcription factor & $\begin{array}{c}\text { Total probe sets in } \\
\text { category on the } \\
\text { GeneChip }\end{array}$ & $\begin{array}{c}\text { No. of ASR- } \\
\text { regulated } \\
\text { transcription factor } \\
\text { probe sets }\end{array}$ \\
\hline WRKY $^{\text {a }}$ & 127 & 46 \\
Myb_DNA_binding $^{\text {a }}$ & 273 & 13 \\
zf-C2H2 & 94 & 11 \\
AP2 / EREBP & 144 & 8 \\
HLH & 114 & 8 \\
GRAS & 92 & 8 \\
NAM & 69 & 8 \\
CCCH & 62 & 4 \\
zf-zf-B_box / zf-C3H & 27 & 4 \\
HSF_DNA-binding & 31 & 3 \\
B3 & 18 & 3 \\
bZIP & 82 & 2 \\
GATA & 15 & 2 \\
CBFD_NFYB_HMF & 19 & 1 \\
Homeobox & 193 & 1 \\
SBP & 7 & 1 \\
zf-C2HC_plant & 1 & 1 \\
zf-Dof & 31 & 1 \\
EIN3 & 15 & 1 \\
TBP & 27 & 1 \\
\hline TOTAL & 1,441 & 127 \\
\hline a & & \\
\hline
\end{tabular}

a Transcription factors associated with stress responses. 
recognized prior to this time, which appears to lead to a derepression of host defenses if this model is correct.

Although the model that ASR actively suppresses host defense responses through the action of effector proteins secreted by the haustoria is attractive, our data suggest that suppression of host responses already was occurring by 18 hai, which is before the time that ASR haustoria are known to form (Koch et al. 1983; Yang 1991). For example, the expression of most flavonoid biosynthetic genes peaks at 12 hai within the early time frame (Fig. 5). This observation may suggest that haustoria can form earlier than in the published literature or that ASR can secrete counterdefensive molecules prior to forming haustoria or that the fungus simply goes undetected once it passes through the epidermis. Regardless of which scenario is correct, these data demonstrate a need for more detailed microscopic examination of the rust infection process in conjunction with host gene expression analyses, which currently are underway.
Potential biological roles of ASR-regulated genes.

Pathogen recognition and signal transduction. Many of the genes regulated by ASR infection previously have been associated with induced plant defenses and may have roles as components of signaling pathways or as effectors of resistance (Bernardo et al. 2007; Caldo et al. 2004, 2006; Eulgem et al. 2004; Golkari et al. 2007; Iqbal et al. 2005; Pritsch et al. 2000; Rinaldi et al. 2007; Venisse et al. 2002). A number of genes with potential regulatory functions in recognition, signal transduction, and transcription are induced (Table 1). Interestingly, most of these genes are differentially expressed in a biphasic manner. The WRKY transcription factors are examples of particular interest because they are significantly overrepresented in our data set (Table 3). WRKY transcription factors change host gene transcription to modulate defenses (Eulgem 2005; Singh et al. 2002). In Arabidopsis, specific WRKY transcription factors are induced rapidly in an NPRl-dependent manner following pathogen recognition (Wang et al. 2006). NPRl it-
Resistant leaves (PI970230)

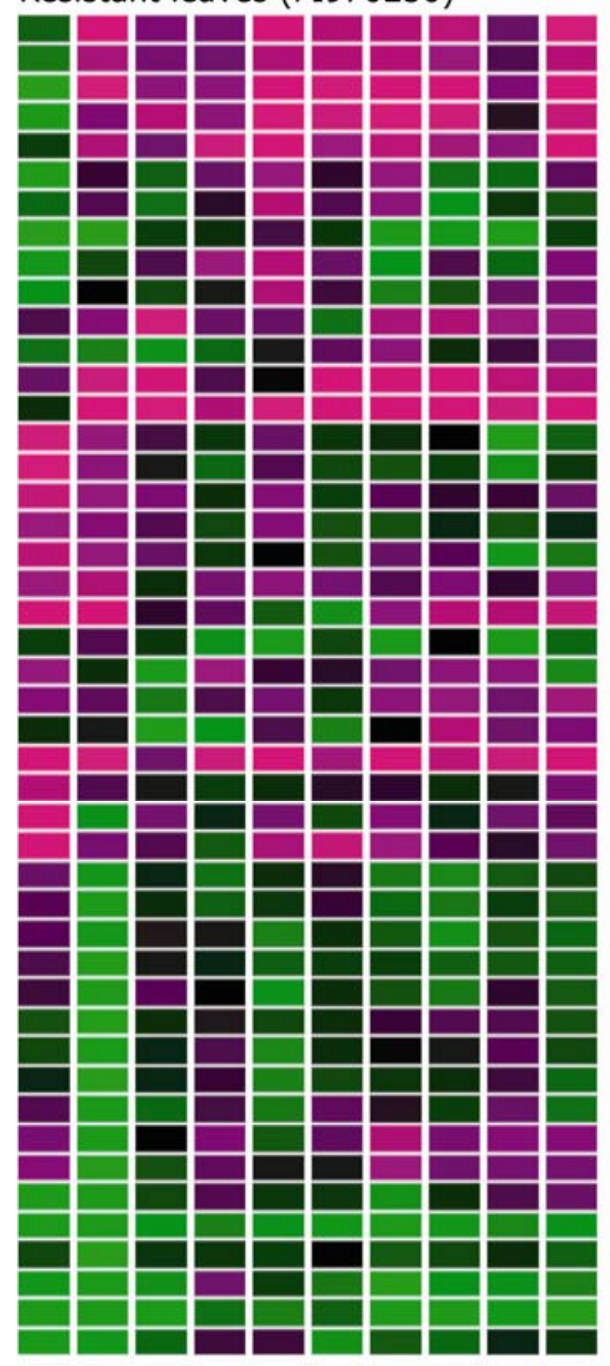

$\begin{array}{llllllllll}6 & 12 & 18 & 24 & 36 & 48 & 72 & 96 & 120 & 168\end{array}$
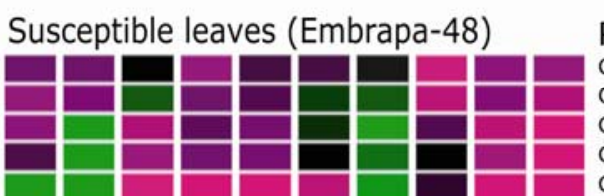

Probe Set

GmaAffx.93343.1.S1_s_at GmaAffx.93343.1.S1_at GmaAffx.12883.1.S1_at GmaAffx.41719.1.S1_at GmaAffx.73009.1.S1_x_at Gma.1256.1.S1_at GmaAffx.73819.1.S1_at GmaAffx.73842.1.S1_at Gma.9913.2.S1_a_at GmaAffx.7166.1.S1_at GmaAffx.6438.2.51_at GmaAffx.51816.1.S1_at Gma.16733.2.S1_at

Gma.16733.1.S1_at GmaAffx.91768.1.S1_s_at Gma.3730.2.51_a_at GmaAffx.6438.3.S1_s_at GmaAffx.6438.3.S1_at GmaAffx.91768.1.S1_at GmaAffx.74525.2.S1_at GmaAffx.33784.1.S1_at Gma.10818.2.S1_a_at GmaAffx.82051.1.S1_at GmaAffx.36938.1.S1_at Gma.744.1.S1_at GmaAffx.73009.1.S1_at GmaAffx.6438.7.S1_at Gma.4400.1.S1_at Gma.4281.1.S1_at GmaAffx.92945.1.S1_x_at GmaAffx.92945.1.S1_at GmaAffx.91389.1.S1_x_at GmaAffx.91389.1.S1_s_at Gma.2526.3.S1_s_at GmaAffx.92842.1.S1_x_at Gma.2526.1.S1_x_at Gma.2526.1.S1_at GmaAffx.69709.1.S1_at GmaAffx.73009.2.51_at GmaAffx.73009.1.S1_s_at GmaAffx.91449.1.S1_at GmaAffx.70101.1.S1_x_at Gma.11203.1.S1_a_at GmaAffx.72876.1.S1_at GmaAffx.70101.1.S1_at GmaAffx.81988.1.S1_at

Arabidopsis homolog WRKY70 WRKY70 WRKY60 WRKY40 WRKY51 . .

WRKY70 WRKY41

WRKY33 WRKY41 WRKY40

WRKY40 WRKY40 WRKY33 WRKY 33 WRKY40 WRKY51 WRKY75 WRKY40 WRKY 33 WRKY 33

WRKY51 WRKY33 WRKY75 WRKY70 WRKY26 WRKY26 WRKY25 WRKY25 WRKY31 WRKY 31 WRKY6 WRKY6 WRKY 31 WRKY51 WRKY51 WRKY 3 WRKY2 WRKY 33 WRKY20

WRKY2 WRKY11

\footnotetext{
Time (hours after inoculation)
}

Fig. 6. Expression profiles of 46 Asian soybean rust-responsive WRKY transcription factor probe sets in susceptible and resistant genotypes. Hierarchical clustering was used to group genes according to the similarity of their expression profiles, which are shown in the heat map. Each row represents a probe set on the Soybean Genome Array and the Arabidopsis homolog (BLAST E value $\leq 10^{-4}$; · indicates no homolog was found and -- indicates the Arabidopsis homolog did not contain a WRKY domain) and each column represents the indicated sampling time. Black boxes represent no change in gene expression compared with the uninfected mock treatment, magenta indicates upregulation, and green indicates downregulation. More intense colors represent greater fold change. 
self is inducible (Yu et al. 2001) and, consistent with this, we found that a soybean NPRI-like sequence represented by probe set GmaAffx.44705.1.S1_at is induced by ASR infection in incompatible interactions at the $2 \%$ FDR. The WRKY transcription factors have both positive and negative regulatory functions that control expression of additional downstream plant effectors of resistance, such as pathogenesis-related genes. There are at least 109 unique WRKY transcription factors in soybean (Zhang and Wang 2005); however, the functions of particular soybean WRKY transcription factors are currently unknown. These up- and downregulated WRKY transcription factors suggest complex positive and negative regulation of soybean defense pathways that will be important to investigate further through functional assays.

A variety of other genes of potential interest in soybean defense signaling are induced as well. We find that ASR causes differential gene expression of receptor-like kinases, various $\mathrm{Ca}^{2+}$ transporter genes, calcium-dependent protein kinases (CDPKs), and mitogen-activated protein kinases (MAPKs), as well as oxidative stress-associated genes such as peroxidases and glutathione S-transferases. Specific signaling pathways appear to be activated upon pathogen recognition in both compatible and incompatible interactions, and these pathways may include changes in free $\mathrm{Ca}^{2+}$ levels, the production of reactive oxygen species, and the post-translational activation of MAPK cascades. These pathways have been associated with the activation of innate immune responses during early infection processes (Garcia-Brugger et al. 2006; Nürnberger et al. 2004).

Metabolic response. A dramatic shift in the expression of genes of the phenylpropanoid pathway is observed in ASR infection. The enzymes encoded by these genes produce defense-related secondary metabolites, which are created through numerous hydroxylation and methylation steps from phenylalanine by cytochrome P450 hydroxylases (CYPs) and $O$-methyltransferases (OMTs), respectively (Fig. 5) (La Camera et al. 2004). Many ASR-regulated CYPs also are classified with electron transport functions (GO:0006118) and, thus, their involvement in the phenylpropanoid pathway also may cause the overrepresentation of electron transport functions. The phenylpropanoid pathway is involved in the biosynthesis of phytoalexins and antimicrobial compounds, including diadzein, genistein, glyceollin, tannins, and cell-wall-reinforcing compounds such as lignans and lignins (Abbasi et al. 2001; Chang et al. 1995; Chiang and Norris 1983; Hahlbrock and Scheel 1989). In both resistant and susceptible plants, mRNAs encoding these enzymes were induced during the early, general defense response against ASR infection, but most genes returned to mock levels by 24 hai. A second induction of the phenylpropanoid pathway occurred during late stages of infection, and the onset was at least 1 day earlier in resistant plants. Temporal changes in gene expression of phenylpropanoid pathway genes also were observed in compatible and incompatible $P$. syringae pv. glycinea interactions (Zabala et al. 2006).

Transport. Genes associated with various transport processes are overrepresented in the ASR dataset. There are four genes involved in ammonium $\left(\mathrm{NH}_{4}{ }^{+}\right)$transport represented on the soybean genome array. Ammonium is bound to trans-cinnamate by phenylalanine ammonia-lyase (PAL), the key regulatory enzyme of the phenylpropanoid pathway, to form L-phenylalanine. Three of the four $\mathrm{NH}_{4}{ }^{+}$transporters were induced in the resistant genotype and two in the susceptible genotype in a temporal pattern that resembles the expression profile of two PAL genes and other genes involved in the phenylpropanoid pathway.

Recent studies of B. graminis f. sp. hordei-challenged barley leaves found upregulation of genes involved in carbohydrate transport (Caldo et al. 2006; Gjetting et al. 2007). We examined our data for carbohydrate transport functions (GO:0008643) and found that 15 of the 71 probe sets of this class that were represented on the soybean genome array were differentially regulated by ASR infection, with the majority being observed in the compatible interaction $(P$ value $<0.05)$ (Table 1$)$. These genes encode components of a sugar transporter superfamily and monosaccharide transporters, including a sorbitol transporter, as well as genes encoding sugar metabolism enzymes (including citrate synthase, isocitrate dehydrogenase, fructose1,6-bisphosphatase, UDP-arabinose 4-epimerase, and trehalose6-phosphate synthase). The largest induction occurred at 12 hai, after which expression levels returned to mock levels. The induction of sugar transport genes during late stages appeared to be stronger in the susceptible genotype and may help to provide nutrients to the fungal infection.

\section{Conclusion.}

To gain insight into the molecular interaction between ASR and its soybean host, we assessed gene expression in resistant and susceptible plants over the course of infection from inoculation to symptom development. Soybean gene expression was induced from 6 to 12 hai; however, unexpectedly, the expression of most host genes returned to mock levels by 24 hai in both the compatible and incompatible interactions. The number of differentially expressed genes remained low during a time when fungal growth also remained low. We hypothesize that timely activation of subsequent defense responses in the resistant genotype prevented the fungus from the rapid growth that was observed in the susceptible genotype at the later time points. The genes identified here provide an extensive list of candidate genes that regulate or affect soybean defense mechanisms or are involved in mediating the successful establishment of this pathogen in soybean leaves. These genes can be tested for their functions in ASR infection as well as for their functions in other soybean-pathogen interactions using recently developed tools for functional analyses (McCallum et al. 2000; Slade and Knauf 2005; Zhang and Ghabrial 2006).

\section{MATERIALS AND METHODS}

\section{Experimental design and inoculation.}

A Brazilian isolate of ASR (verified by PCR analysis) was collected from soybean fields in 2002 in the state of Mato Grosso near the cities of Rondonopolis and Primavera do Leste and maintained for over 10 generations on the susceptible cv. BRS154 in a separate greenhouse at Embrapa-soja in Londrina, Brazil. The Embrapa-48 genotype was used as a susceptible host plant, which develops a susceptible (tan) lesion after ASR infection, and PI230970 was used as a resistant host, which contains the ASR resistance gene Rpp2 and develops a reddish-brown lesion type (Fig. 1). Urediniospores of the ASR isolate were collected and resuspended to $1.1 \times 10^{5}$ spores $/ \mathrm{ml}$ in sterile distilled water containing $0.5 \%$ Tween-20. Three plants per pot were inoculated at the V6 to V8 growth stage (Fehr and Caviness 1977) by misting approximately $9 \mathrm{ml}$ of spore solution onto the top surface of the leaves. The same solution minus spores was used for the mock inoculations. The inoculations were performed in the evening beginning at 1800 $\mathrm{h}$ to allow the infection process to occur in the dark. Following the ASR or mock inoculations, water-misted bags were placed over all plants for 2.5 days to aid the infection process and to prevent cross-contamination of mock-infected plants. The fifth trifoliolate leaves of two plants were collected for microarray analysis during the first 7 days of infection, as well as at 11 dai to assess fungal accumulation in infected plants. The experiment followed a randomized complete block design with the three replicates as blocks and with a full factorial treatment structure 
with three treatment factors. The three treatment factors were the time (10 levels), genotype (resistant or susceptible), and infection type (ASR or mock).

\section{Tissue collection and RNA isolation.}

The three leaflets of the fifth trifoliolate leaf of two plants were collected at $6,12,18,24,36,48,72,96,120$, and 168 hai and immediately frozen in liquid nitrogen and stored at $-80^{\circ} \mathrm{C}$. Leaf tissue was ground in liquid nitrogen, and RNA was extracted using $1 \mathrm{ml}$ of RNAwiz (Ambion, Austin, TX, U.S.A.). After precipitation of RNA in 2-propanol, the samples were stored at $-80^{\circ} \mathrm{C}$ and then shipped to Iowa State University, where the extraction protocol was completed and the RNA samples were resuspended in $100 \mu$ of diethyl pyrocarbonate (DEPC)-treated water containing RNAseOUT (Invitrogen, Carlsbad, CA, U.S.A.) at $2 \mathrm{U} / \mu \mathrm{l}$. RNA samples were further purified by precipitation in $2 \mathrm{M}$ lithium chloride (final concentration) (Ausubel et al. 1994) followed by RNeasy column purification (Qiagen, Valencia, CA, U.S.A.) and elution in 30 $\mu l$ of DEPC-treated water.

\section{Assessment of fungal mRNA accumulation.}

Fungal growth was assessed by quantifying the constitutively expressed ASR $\alpha$-tubulin gene (R. D. Frederick, personal communication) by TaqMan qRT-PCR (Table 4; primer and TaqMan probe sequences). The iScript One-Step RT-PCR kit for probes (Bio-Rad, Hercules, CA, U.S.A.) was used according to the manufacturer's protocol with $50 \mathrm{ng}$ of RNA, $300 \mathrm{nM}$ final concentration primers, and $150 \mathrm{nM}$ probe in the following RTPCR program: cDNA synthesis for $10 \mathrm{~min}$ at $50^{\circ} \mathrm{C}$, iScript reverse transcription inactivation for $5 \mathrm{~min}$ at $95^{\circ} \mathrm{C}$, PCR cycling at $95^{\circ} \mathrm{C}$ for $10 \mathrm{~s}$, and data collection for $30 \mathrm{~s}$ at the extension temperature of $60^{\circ} \mathrm{C}$ for 45 cycles. Expression data were normalized to the soybean ubiquitin-3 gene (GenBank accession number gi 456713, dbj D28123.1), which showed no evidence for differential expression in our experiments.

\section{Microarray labeling, hybridization, and scanning.}

RNA samples were adjusted to a concentration of $0.6 \mu \mathrm{g} / \mu \mathrm{l}$ and soybean mRNA transcript abundance was measured using the GeneChip Soybean Genome Arrays (Affymetrix, Santa Clara, CA, U.S.A.). RNA concentration and quality were determined using a NanoDrop spectrophotometer (NanoDrop Tech- nologies, Wilmington, DE, U.S.A.) and by RNA Nano LabChip on a 2100 Bioanalyzer (Agilent Technologies, Inc., Palo Alto, CA, U.S.A.). All steps in labeling, hybridization, and scanning were performed at the Iowa State University GeneChip Facility. Synthesis of labeled target cRNA used $5 \mu \mathrm{g}$ of total RNA and was performed using the GeneChip One-Cycle Target Labeling and Control Reagents kit (Affymetrix) according to the manufacturer's instructions. Fragmented cRNA (10 $\mu \mathrm{g})$ was hybridized to GeneChip Soybean Genome Arrays (Affymetrix) according to the manufacturer's instructions. Quality of fragmented cRNA was verified on an Agilent 2100 BioAnalyzer equipped with an RNA Nano LabChip. Washes were performed using the EukGE-WS2v5_450 washing protocol, and microarrays were scanned with a GCS3000 7G scanner (Affymetrix).

\section{Statistical analysis of microarray data.}

The base 2 logarithm of MAS5.0 signals were median centered so that the median log-scale expression measure for each GeneChip was zero. Linear model analysis of these normalized log-scale expression measures was performed separately for each gene using SAS (version 9.1; SAS Institute, Cary, NC, U.S.A.). Each linear model included fixed replication effects and fixed effects for times, genotypes, infection types, and all possible interactions between these three factors of interest. SAS contrast statements were used to obtain $P$ values from $F$ statistics for the tests of infection type main effect and infection type-time interaction effect within each genotype. These tests were used to determine, respectively, whether there was significant evidence of an expression difference between infection types when averaging over time within each genotype and whether there was significant evidence that the pattern of expression over time differed with infection type within each genotype. Together, these tests were used to search for genes whose expression differs in some manner (either in level, pattern over time, or both) between infection types within each genotype. A $q$ value was computed for each $P$ value using the method described by Storey and Tibshirani (2003). The $q$ values were used to produce lists of differentially expressed genes with estimated FDRs of 5\%. Hierarchical clustering in $\mathrm{R}$ programming language for statistical computing using the Agnes function was performed on the standardized base 2 logarithm of fold change in gene expression on various data sets according to test results. Hierarchical clustering using

Table 4. Primer sets and reaction conditions used in quantitative reverse-transcriptase polymerase chain reaction

\begin{tabular}{|c|c|c|c|c|c|}
\hline Target & Primer set (forward and reverse primer) & $\begin{array}{l}\text { Amplicon } \\
\text { size (bp) }\end{array}$ & $\begin{array}{c}\text { Temperature } \\
\left({ }^{\circ} \mathbf{C}\right)^{\mathbf{a}}\end{array}$ & $\begin{array}{l}\text { No. of } \\
\text { cycles }\end{array}$ & Reference \\
\hline Ubiquitin- $3^{\mathrm{b}}$ & $\begin{array}{l}\text { GTGTAATGTTGGATGTGTTCCC } \\
\text { ACACAATTGAGTTCAACACAAACCG }\end{array}$ & 107 & 65 & 35 & Trevaskis et al. 2002 \\
\hline Gma.3713.1.S1_s_at & $\begin{array}{l}\text { GTACGCTTCCCTTACCTTTGTGGT } \\
\text { TCGCGGTTTGTGTCGAGAACGTAT }\end{array}$ & 81 & 65 & 35 & This study \\
\hline GmaAffx.4296.1.S1_at & $\begin{array}{l}\text { TCCTCTTCCGTGCCTCCAAATTGA } \\
\text { TCCAGGATAAGCAGGCGGGTATTT }\end{array}$ & 152 & 65 & 45 & This study \\
\hline GmaAffx.4552.1.S1_s_at & $\begin{array}{l}\text { TCTTGTTTCTAAGGAATAGACCAA } \\
\text { CAAGAAACGACAATGATTCAACTG }\end{array}$ & 117 & 62 & 35 & This study \\
\hline GmaAffx.46129.1.S1_at & $\begin{array}{l}\text { GGAATCTCATGAAAGAGGAATTTCTAGATG } \\
\text { TCAAAGCCAAACATGCTATATGTGC }\end{array}$ & 141 & 58 & 45 & This study \\
\hline GmaAffx.46214.4.S1_at & $\begin{array}{l}\text { CTCTTGAACTCTTTCTCCTCTTGACTC } \\
\text { GAGCGACCTATGATAAATCACACAC }\end{array}$ & 80 & 63 & 45 & This study \\
\hline GmaAffx.69949.1.S1_at & $\begin{array}{l}\text { TCGCACTTCCACCTTCCATCTA } \\
\text { GTAGCCTCCTTTATTCAGTATACAAAC }\end{array}$ & 80 & 63 & 45 & This study \\
\hline GmaAffx.91194.1.S1_at & $\begin{array}{l}\text { TCAAGCACCCTCTGATGAACTC } \\
\text { CTCAGTACGTACACATAGACGACC }\end{array}$ & 130 & 63 & 35 & This study \\
\hline Phakopsora pachyrhizi $\alpha$-tubulin ${ }^{\mathrm{c}}$ & $\begin{array}{l}\text { CCAAGGCTTCTTCGTGTTTCA } \\
\text { CAAGAGAAGAGCGCCAAACC }\end{array}$ & n.a. & 60 & 45 & $\begin{array}{l}\text { R. D. Frederick, personal } \\
\text { communication }\end{array}$ \\
\hline
\end{tabular}

${ }^{a}$ Temperature of annealing and extension used for each primer set.

b 3' Untranslated region (UTR) of Glycine max SUBI-3 gene for ubiquitin [gi456713 | D28123].

c TaqMan probe: 5' FAM-TCGTTTGGAGGCGGACTGGTTCA-3' Blackhole1; n.a. = not applicable. 
Pearson correlation with complete linkage in GeneSpring GX (Agilent Technologies, Inc.) was performed for clustering the base 2 logarithm of the fold change in gene expression of the ASR-regulated WRKY transcription factor probe sets (Fig. 6).

\section{Gene annotation.}

The ASR-regulated genes were annotated using the Affymetrix GeneChip Soybean Genome Array Annotation page developed as part of SoyBase and The Soybean Breeder's Toolbox. The website allows users to upload a file of probe set identifiers and download the corresponding available annotation data. The provided annotation data was generated by comparing the Soybean Genome Array consensus sequences, from which the probe sets were designed, with three different sequence databases using BLASTX (Altschul et al. 1997) at an E value cutoff of $10^{-4}$. First, the consensus sequences were compared with the UniProt protein database (version June 2006) (Apweiler et al. 2004) and the top three hits were reported, including a description of the hit, the percent overlap between the query and the hit, the percent amino acid identify, and the $E$ value. Second, the consensus sequences were compared with the Pfam protein database (version June 2006) (Bateman et al. 2004), reporting the top hit and corresponding E value. Finally, the consensus sequences were compared with the predicted coding sequences from the Arabidopsis thaliana genome (The Arabidopsis Information Resource [TAIR], TAIR6_cds_ 20051108). The TAIR GO and GO slim annotations (Berardini et al. 2004) are provided for each A. thaliana sequence identified.

\section{qRT-PCR analysis of soybean genes.}

Expression levels of selected probe sets were quantified by qRT-PCR analysis using iScript One-Step RT-PCR kit with SYBR Green (Bio-Rad, Hercules, CA, U.S.A.) according to the manufacturer's protocol. RNA (10 ng) was used in the following RT-PCR program: cDNA synthesis for $10 \mathrm{~min}$ at $50^{\circ} \mathrm{C}$, iScript reverse transcription inactivation for $5 \mathrm{~min}$ at $95^{\circ} \mathrm{C}$, PCR cycling at $95^{\circ} \mathrm{C}$ for $10 \mathrm{~s}$, data collection for $30 \mathrm{~s}$ at the extension temperature (Table 4 lists annealing and extension temperature and number of cycles), and ending with a standard melt curve analysis. Relative quantification was performed using the standard curve method, and transcript accumulation of each gene was normalized to the quantity of constitutively expressed soybean ubiquitin-3 gene, which does not respond to ASR infection. The fold change was calculated by dividing the relative expression level of the ASR-infected sample by the corresponding mock-inoculated sample. These values were transformed by the log of base 2 to generate the relative fold change for each probe set.

\section{ACKNOWLEDGMENTS}

We thank A. Flausino, L. Benato, N. Valentin, and V. Santos for their assistance during ASR inoculation; J. Peng for processing of the RNA samples for GeneChip analysis; R. Frederick, M. Posada-Buitrago, and L. Ewing for ASR primers and probe design and qRT-PCR protocol; and T. Maier, S. Marin, V. Pierote, R. Stolf, D. da Silva, M. Beneventi, and N. Vieira for their contributions to this research. This work was supported by the Iowa State University Plant Sciences Institute, Embrapa-Soja, and the Iowa Soybean Association.

\section{LITERATURE CITED}

Abbasi, P. A., Graham, M. Y., and Graham, T. L. 2001. Effects of soybean genotype on the glyceollin elicitation competency of cotyledon tissues to Phytophthora sojae glucan elicitors. Physiol. Mol. Plant Pathol. 59:95-105.

Alkharouf, N. W., Klink, V. P., Chouikha, I. B., Beard, H. S., Macdonald, M. H., Meyer, S., Knap, H. T., Khan, R., and Matthews, B. F. 2006.
Timecourse microarray analyses reveal global changes in gene expression of susceptible Glycine max (soybean) roots during infection by Heterodera glycines (soybean cyst nematode). Planta 224:838-852.

Altschul, S. F., Madden, T. L., Schäffer, A. A., Zhang, J., Zhang, Z. Miller, W., and Lipman, D. J. 1997. Gapped BLAST and PSI-BLAST: a new generation of protein database search programs. Nucleic Acids Res. 25:3389-3402

Apweiler, R., Bairoch, A., Wu, C. H., Barker, W. C., Boeckmann, B., Ferro, S., Gasteiger, E., Huang, H., Lopez, R., Magrane, M., Martin, M. J., Natale, D. A., O’Donovan, C., Redaschi, N., and Yeh, L.-S. L. 2004 UniProt-the Universal Protein knowledgebase. Nucleic Acids Res. 32:D115-119.

Ausubel, F. M., Brent, R., Kingston, R. E., Moore, D. D., Seidman, J. G., Smith, J. A., and Struhl, K. 1994. Current Protocols in Molecular Biology. John Wiley \& Sons Inc, Hoboken, NJ, U.S.A.

Bateman, A., Coin, L., Durbin, R., Finn, R. D., Hollich, V., Griffiths-Jones, S., Khanna, A., Marshall, M., Moxon, S., Sonnhammer, E. L. L. Studholme, D. J., Yeats, C., and Eddy, S. R. 2004. The Pfam protein families database. Nucleic Acids Res. 32:D138-141.

Baureithel, K., Felix, G., and Boller, T. 1994. Specific, high affinity binding of chitin fragments to tomato cells and membranes. Competitive inhibition of binding by derivatives of chitooligosaccharides and a Nod factor of Rhizobium. J. Biol. Chem. 269:17931-17938.

Berardini, T. Z., Mundodi, S., Reiser, L., Huala, E., Garcia-Hernandez, M., Zhang, P., Mueller, L. A., Yoon, J., Doyle, A., Lander, G., Moseyko, N., Yoo, D., Xu, I., Zoeckler, B., Montoya, M., Miller, N., Weems, D., and Rhee, S. Y. 2004. Functional annotation of the Arabidopsis genome using controlled vocabularies. Plant Physiol. 135:745-755.

Bernardo, A., Bai, G., Guo, P., Xiao, K., Guenzi, A. C., and Ayoubi, P. 2007. Fusarium graminearum-induced changes in gene expression between Fusarium head blight-resistant and susceptible wheat cultivars. Funct. Integr. Genomics 7:69-77.

Birch, P. R. J., Rehmany, A. P., Pritchard, L., Kamoun, S., and Beynon, J. L. 2006. Trafficking arms-Oomycete effectors enter host plant cells Trends Microbiol. 14:8-11.

Boddu, J., Cho, S., Kruger, W. M., and Muehlbauer, G. J. 2006. Transcriptome analysis of the barley-Fusarium graminearum interaction. Mol. Plant-Microbe Interact. 19:407-417.

Bonde, M. R., Melching, J. S., and Bromfield, K. R. 1976. Histology of suscept-pathogen relationship between Glycine max and Phakopsora pachyrhizi, cause of soybean rust. Phytopathology 66:1290-1294.

Bonde, M. R., Nester, S. E., Austin, C. N., Stone, C. L., Frederick, R. D., Hartman, G. L., and Miles, M. R. 2006. Evaluation of virulence of Phakopsora pachyrhizi and P. meibomiae isolates. Plant Dis. 90:708-716.

Bromfield, K. R. 1984. Soybean Rust, Monograph No. 11. American Phytopathological Society, St. Paul, MN, U.S.A.

Bromfield, K. R., and Hartwig, E. E. 1980. Resistance to soybean rust and mode of inheritance. Crop Sci. 20:254-255.

Bruce, R. J., and West, C. A. 1982. Elicitation of casbene synthetase activity in castor bean - the role of pectic fragments of the plant cell wall in elicitation by a fungal endopolygalacturonase. Plant Physiol. 69:11811188.

Bruggmann, R., Abderhalden, O., Reymond, P., and Dudler, R. 2005. Analysis of epidermis- and mesophyll-specific transcript accumulation in powdery mildew-inoculated wheat leaves. Plant Mol. Biol. 58:247267.

Caldo, R. A., Nettleton, D., and Wise, R. P. 2004. Interaction-dependent gene expression in $M l a$-specified response to barley powdery mildew. Plant Cell 16:2514-2528.

Caldo, R. A., Nettleton, D., Peng, J., and Wise, R. P. 2006. Stage-specific suppression of basal defense discriminates barley plants containing fastand delayed-acting Mla powdery mildew resistance alleles. Mol. PlantMicrobe Interact. 19:939-947.

Catanzariti, A.-M., Dodds, P. N., and Ellis, J. G. 2007. Avirulence proteins from haustoria-forming pathogens. FEMS (Fed. Eur. Microbiol. Soc.) Microbiol. Lett. 269:181-188.

Chang, Y. C., Nair, M. G., and Nitiss, J. L. 1995. Metabolites of diadzein and genistein and their biological activities. J. Nat. Prod. 58:1901-1905.

Cheng, Y. W., and Chan, K. L. 1968. The breeding of 'Tainung 3' soybean J. Taiwan Agric. Res. 17:30-35.

Chiang, H.-S., and Norris, D. M. 1983. Phenolic and tannin contents as related to anatomical parameters of soybean resistance to agromyzid bean flies. J. Agric. Food Chem. 31:726-730.

Dangl, J. L., and Jones, J. D. G. 2001. Plant pathogens and integrated defence responses to infection. Nature 411:826-833.

Davis, K. R., and Hahlbrock, K. 1987. Induction of defense responses in cultured parsley cells by plant cell wall fragments. Plant Physiol. 84:1286-1290.

Dodds, P. N., Lawrence, G. J., Catanzariti, A.-M., Ayliffe, M. A., and Ellis, J. G. 2004. The Melampsora lini AvrL567 avirulence genes are ex- 
pressed in haustoria and their products are recognized inside plant cells. Plant Cell 16:755-768.

Drăghici, S., Khatri, P., Martins, R. P., Ostermeier, G. C., and Krawetz, S. A. 2003. Global functional profiling of gene expression. Genomics 81:98-104.

Ellis, J., Catanzariti, A.-M., and Dodds, P. 2006. The problem of how fungal and oomycete avirulence proteins enter plant cells. Trends Plant Sci. 11:61-63.

Enkerli, J., Felix, G., and Boller, T. 1999. The enzymatic activity of fungal xylanase is not necessary for its elicitor activity. Plant Physiol. 121:391398

Eulgem, T. 2005. Regulation of the Arabidopsis defense transcriptome. Trends Plant Sci. 10:71-78.

Eulgem, T., Weigman, V. J., Chang, H. S., McDowell, J. M., Holub, E. B., Glazebrook, J., Zhu, T., and Dangl, J. L. 2004. Gene expression signatures from three genetically separable resistance gene signaling pathways for downy mildew resistance. Plant Physiol. 135:1129-1144.

Fehr, W. R., and Caviness, C. E. 1977. Stages of soybean development. Special Report 80. Iowa State University of Science and Technology, Iowa Agriculture and Home Economics Experiment Station, Ames, U.S.A.

Fisher, R. A. 1966. The Design of Experiments, 8th ed. Oliver and Boyd, Edinburgh, U.K.

Garcia-Brugger, A., Lamotte, O., Vandelle, E., Bourque, S., Lecourieux, D., Poinssot, B., Wendehenne, D., and Pugin, A. 2006. Early signaling events induced by elicitors of plant defenses. Mol. Plant-Microbe Interact. 19:711-724.

Gjetting, T., Hagedorn, P. H., Schweizer, P., Thordal-Christensen, H., Carver, T. L. W., and Lyngkjær, M. F. 2007. Single-cell transcript profiling of barley attacked by the powdery mildew fungus. Mol. PlantMicrobe Interact. 20:235-246.

Golkari, S., Gilbert, J., Prashar, S., and Procunier, J. D. 2007. Microarray analysis of Fusarium graminearum-induced wheat genes: identification of organ-specific and differentially expressed genes. Plant Biotechnol. J. 5:38-49.

Hahlbrock, K., and Scheel, D. 1989. Physiology and molecular biology of phenylpropanoid metabolism. Annu. Rev. Plant Physiol. Plant Mol. Biol. 40:347-369.

Hahn, M., Neef, U., Struck, C., Gottfert, M., and Mendgen, K. 1997. A putative amino acid transporter is specifically expressed in haustoria of the rust fungus Uromyces fabae. Mol. Plant-Microbe Interact. 10:438-445.

Hartwig, E. E. 1986. Identification of a fourth major gene conferring resistance to soybean rust. Crop Sci. 26:1135-1136.

Hidayat, O. O., and Somaatmadja, S. 1977. Screening of soybean breeding lines for resistance to soybean rust (Phakopsora pachyrhizi Sydow). Soybean Rust Newsl. 1:9-22.

Hoppe, H. H., and Koch, E. 1989. Defense reactions in host and nonhost plants against the soybean rust fungus (Phakopsora pachyrhizi Syd). J. Phytopathol. 125:77-88.

Iqbal, M. J., Yaegashi, S., Ahsan, R., Shopinski, K. L., and Lightfoot, D. A. 2005. Root response to Fusarium solani f. sp . glycines-temporal accumulation of transcripts in partially resistant and susceptible soybean. Theor. Appl. Genet. 110:1429-1438.

Ithal, N., Recknor, J., Nettleton, D., Hearne, L., Maier, T., Baum, T. J., and Mitchum, M. G. 2007. Parallel genome-wide expression profiling of host and pathogen during soybean cyst nematode infection of soybean. Mol. Plant-Microbe Interact. 20:293-305

Kaku, H., Nishizawa, Y., Ishii-Minami, N., Akimoto-Tomiyama, C., Dohmae, N., Takio, K., Minami, E., and Shibuya, N. 2006. Plant cells recognize chitin fragments for defense signaling through a plasma membrane receptor. Proc. Natl. Acad. Sci. U.S.A. 103:11086-11091.

Kemen, E., Kemen, A., Rafiqi, M., Hempel, U., Mendgen, K., Hahn, M., and Voegele, R. 2005. Identification of a protein from rust fungi transferred from haustoria into infected plant cells. Mol. Plant-Microbe Interact. 18:1130-1139.

Koch, E., Ebrahim-Nesbat, F., and Hoppe, H. H. 1983. Light and electronmicroscopic studies on the development of soybean rust (Phakopsora pachyrhizi Syd) in susceptible soybean leaves. Phytopathol. Z. 106:302320

La Camera, S., Gouzerh, G., Dhondt, S., Hoffmann, L., Fritig, B., Legrand, M., and Heitz, T. 2004. Metabolic reprogramming in plant innate immunity-The contributions of phenylpropanoid and oxylipin pathways. Immunol. Rev. 198:267-284.

Mackey, D., and McFall, A. J. 2006. MAMPs and MIMPs-proposed classifications for inducers of innate immunity. Mol. Microbiol. 61:1365-1371.

Marchetti, M. A., Uecker, F. A., and Bromfield, K. R. 1975. Uredial development of Phakopsora pachyrhizi in soybeans. Phytopathology 65:822823.

McCallum, C. M., Comai, L., Greene, E. A., and Henikoff, S. 2000. Targeted screening for induced mutations. Nat. Biotechnol. 18:455-457.
McLean, R. J. 1979. Histological studies of resistance to soybean rust, Phakopsora pachyrhizi Syd. Aust. J. Agric. Res. 30:77-84.

Miles, M. R., Frederick, R. D., and Hartman, G. L. 2006. Evaluation of soybean germplasm for resistance to Phakopsora pachyrhizi. Online. Plant Health Progress doi:10.1094/PHP-2006-0104-01-RS. Published online.

Mithöfer, A., Fliegmann, J., Neuhaus-Url, G., Schwarz, H., and Ebel, J. 2000. The hepta- $\beta$-glucoside elicitor-binding proteins from legumes represent a putative receptor family. Biol. Chem. 381:705-713.

Moy, P., Qutob, D., Chapman, B. P., Atkinson, I., and Gijzen, M. 2004. Patterns of gene expression upon infection of soybean plants by Phytophthora sojae. Mol. Plant-Microbe Interact. 17:1051-1062.

Nettleton, D. 2006. A discussion of statistical methods for design and analysis of microarray experiments for plant scientists. Plant Cell 18:2112-2121.

Nürnberger, T., Brunner, F., Kemmerling, B., and Piater, L. 2004. Innate immunity in plants and animals - striking similarities and obvious differences. Immunol. Rev. 198:249-266.

Ogle, H. J., Byth, D. E., and McLean, R. 1979. Effect of rust (Phakopsora pachyrhizi) on soybean yield and quality in South-eastern Queensland. Aust. J. Agric. Res. 30:883-893.

Parkinson, H., Kapushesky, M., Shojatalab, M., Abeygunawardena, N., Coulson, R., Farne, A., Holloway, E., Kolesnykov, N., Lilja, P., Lukk, M., Mani, R., Rayner, T., Sharma, A., William, E., Sarkans, U., and Brazma, A. 2007. ArrayExpress - a public database of microarray experiments and gene expression profiles. Nucleic Acids Res. 35:D747750.

Patil, V. S., Wuike, R. V., Thakare, C. S., and Chirame, B. B. 1997. Viability of uredospores of Phakopsora phachyrhizi Syd. at different storage conditions. J. Maharashtra Agric. Univ. 22:260-261.

Pritsch, C., Muehlbauer, G. J., Bushnell, W. R., Somers, D. A., and Vance, C. P. 2000. Fungal development and induction of defense response genes during early infection of wheat spikes by Fusarium graminearum. Mol. Plant-Microbe Interact. 13:159-169.

Rinaldi, C., Kohler, A., Frey, P., Duchaussoy, F., Ningre, N., Couloux, A., Wincker, P., Le Thiec, D., Fluch, S., Martin, F., and Duplessis, S. 2007. Transcript profiling of poplar leaves upon infection with compatible and incompatible strains of the foliar rust Melampsora larici-populina. Plant Physiol. doi:144:347-366.

Ron, M., and Avni, A. 2004. The receptor for the fungal elicitor ethyleneinducing xylanase is a member of a resistance-like gene family in tomato. Plant Cell 16:1604-1615.

Rushton, P. J., and Somssich, I. E. 1998. Transcriptional control of plant genes responsive to pathogens. Curr. Opin. Plant Biol. 1:311-315.

Ryan, C. A., Bishop, P. D., Graham, J. S., Broadway, R. M., and Duffey, S. S. 1986. Plant and fungal cell wall fragments activate expression of proteinase inhibitor genes for plant defense. J. Chem. Ecol. 12:1025-1036.

Sato, T., and Sato, S. 1982. Infective ability of soybean rust to several leguminous plants. Soybean Rust Newsl. 5:22-26.

Shibuya, N., Kaku, H., Kuchitsu, K., and Maliarik, M. J. 1993. Identification of a novel high-affinity binding site for $\mathrm{N}$-acetylchitooligosaccharide elicitor in the membrane fraction from suspension-cultured rice cells. FEBS (Fed. Eur. Biol. Soc.) Lett. 329:75-78.

Singh, B. B., and Thapliyal, P. N. 1977. Breeding for resistance to soybean rust in India. Pages 62-65 in: Rust of Soybean-The Problem and Research Needs. R. E. Ford and J. B. Sinclair, eds. Report of a Workshop held in Manila, The Philippines, February 28-March 4, 1977. College of Agriculture, University of Illinois at Urbana-Champaign, U.S.A.

Singh, K. B., Foley, R. C., and Oñate-Sánchez, L. 2002. Transcription factors in plant defense and stress responses. Curr. Opin. Plant Biol. 5:430436.

Slade, A. J., and Knauf, V. C. 2005. TILLING moves beyond functional genomics into crop improvement. Transgenic Res. 14:109-115.

Staples, R. C. 2000. Research on the rust fungi during the twentieth century. Annu. Rev. Phytopathol. 38:49-69.

Staples, R. C. 2001. Nutrients for a rust fungus-the role of haustoria Trends Plant Sci. 6:496-498.

Storey, J. D., and Tibshirani, R. 2003. Statistical significance for genomewide studies. Proc. Natl. Acad. Sci. U.S.A. 100:9440-9445.

Trevaskis, B., Wandrey, M., Colebatch, G., and Udvardi, M. K. 2002. The soybean $G m N 6 L$ gene encodes a late nodulin expressed in the infected zone of nitrogen-fixing nodules. Mol. Plant-Microbe Interact. 15:630-636.

Venisse, J. S., Malnoy, M., Faize, M., Paulin, J. P., and Brisset, M. N. 2002. Modulation of defense responses of Malus spp. during compatible and incompatible interactions with Erwinia amylovora. Mol. PlantMicrobe Interact. 15:1204-1212.

Voegele, R. T., and Mendgen, K. 2003. Rust haustoria: nutrient uptake and beyond. New Phytol. 159:93-100.

Wang, D., Weaver, N. D., Kesarwani, M., and Dong, X. 2005. Induction of 
protein secretory pathway is required for systemic acquired resistance. Science 308:1036-1040.

Wang, D., Amornsiripanitch, N., and Dong, X. 2006. A genomic approach to identify regulatory nodes in the transcriptional network of systemic acquired resistance in plants. PLoS Pathog. 2:e123.

Wise, R. P., Caldo, R. A., Hong, L., Shen, L., Cannon, E. K., and Dickerson, J. A. 2007. BarleyBase/PLEXdb-a unified expression profiling database for plants and plant pathogens. Pages 347-363 in: Methods in Molecular Biology, Vol. 406, Plant Bioinformatics-Methods and Protocols. D. Edwards, ed. Humana Press, Totowa, NJ, U.S.A.

Yamaguchi, T., Yamada, A., Hong, N., Ogawa, T., Ishii, T., and Shibuya, N. 2000. Differences in the recognition of glucan elicitor signals between rice and soybean- $\beta$-glucan fragments from the rice blast disease fungus Pyricularia oryzae that elicit phytoalexin biosynthesis in suspension-cultured rice cells. Plant Cell 12:817-826.

Yang, C. Y. 1991. Soybean Rust Caused by Phakopsora pachyrhizi. Asian Vegetable Research and Development Center, Bangkok, Thailand.

Yu, D., Chen, C., and Chen, Z. 2001. Evidence for an important role of WRKY DNA binding proteins in the regulation of NPRl gene expression. Plant Cell 13:1527-1539.

Zabala, G., Zou, J., Tuteja, J., Gonzalez, D. O., Clough, S. J., and Vodkin,
L. O. 2006. Transcriptome changes in the phenylpropanoid pathway of Glycine max in response to Pseudomonas syringae infection. BMC Plant Biol. 6:26.

Zhang, C., and Ghabrial, S. A. 2006. Development of Bean pod mottle virus-based vectors for stable protein expression and sequence-specific virus-induced gene silencing in soybean. Virology 344:401-411.

Zhang, Y., and Wang, L. 2005. The WRKY transcription factor superfamily-its origin in eukaryotes and expansion in plants. BMC Evol. Biol. 5:1.

Zou, J., Rodriguez-Zas, S., Aldea, M., Li, M., Zhu, J., Gonzalez, D. O., Vodkin, L. O., DeLucia, E., and Clough, S. J. 2005. Expression profiling soybean response to Pseudomonas syringae reveals new defenserelated genes and rapid HR-specific downregulation of photosynthesis. Mol. Plant-Microbe Interact. 18:1161-1174.

\section{AUTHOR-RECOMMENDED INTERNET RESOURCES}

ArrayExpress database: www.ebi.ac.uk/arrayexpress

Plant Expression database (PlexDB): plexdb.org

SoyBase Affymetrix GeneChip Soybean Genome Array Annotation website: www.soybase.org/AffyChip 